\title{
Tinha uma vírgula no meio da frase: considerações sobre as prescrições do emprego do sinal ${ }^{1}$ \\ There was a comma in the middle of the sentence: considerations about the prescriptions of the use of this punctuation mark
}

\author{
Leandro Vidal Carneiro* \\ Mônica Magalhães Cavalcante ${ }^{* *}$
}

RESUMO: Apresentamos os resultados de uma pesquisa em que se buscou verificar a abordagem das Gramáticas Normativas (GN) sobre o emprego da vírgula nas frases em português. A pesquisa faz parte de um projeto maior, realizado por integrantes do Protexto - UFC/Fortaleza, que investigou como vários outros fenômenos linguísticos são abordados pelas GN. O corpus constituise de cinco GN e de um livro especializado no assunto do emprego do sinal de pontuação em foco. Para a coleta dos dados, realizou-se uma leitura do que cada autor diz sobre os casos em que o sinal deve ou não ser utilizado e, por meio de um método comparativo, procurou-se destacar as semelhanças e as diferenças entre as regras apresentadas nas obras. Os resultados apontam as muitas divergências no tratamento do assunto, tais como as contradições, em um mesmo compêndio; as incompatibilidades entre as regras que, para o mesmo ambiente sintático, ora recomendam o uso da vírgula, ora não; a ausência de regras que prescrevam os casos onde o sinal não deve ser utilizado; a vagueza na exposição das regras, não compensada pelos exemplos dados, entre outras.

PALAVRAS-CHAVE: Vírgula. Regras. Gramática normativa.
ABSTRACT: In this article we present the results of a research in which we tried to verify the approach of Normative Grammars (NG) about the use of the comma in Portuguese sentences. This research is part of a major project, performed by members of ProtextoUFC/Fortaleza, which tried to investigate how many other linguistic phenomena are approached by NG. The corpus is constituted by Five NG and a specialized book in the topic at issue: the punctuation mark comma. To collect the data, we read what each author said about the cases in which the mark should or not be used. Through a comparative method we tried to highlight the similarities and differences about the rules presented in their works. The results indicate many divergences in the subject usage, just like contradictions in a same compendium, between rules that in the same syntactic environment, at times affirm the use of the mark, at other times deny it; the absence of rules in one of the works that prescript the cases in which the mark should not be used; vagueness in the rules exposition, not rewarded by the given examples, inter alia.

KEYWORDS: Comma. Rules. Normative grammar.

\footnotetext{
${ }^{1}$ O presente trabalho é o resultado de uma pesquisa maior - totalmente desenvolvida por alunos da graduação integrantes do PROTEXTO - em que se buscou investigar como as normas de concordância, regência, colocação e virgulação são apresentadas nas GN. O interesse pela investigação surgiu a partir dos questionamentos e reflexões dos alunos das disciplinas Texto e Discurso e Língua Portuguesa: Frase, do curso de Letras da UFC/Fortaleza, quando nas aulas se discutiam os critérios das competências avaliadas pelo Exame Nacional do Ensino Médio para a correção da redação dos participantes. * Aluno graduando em Letras pela Universidade Federal do Ceará, UFC/Fortaleza.

** Doutora em Linguística Textual pela Universidade Federal de Pernambuco. Atua como Professor Assistente na Universidade Federal do Ceará, onde desenvolve pesquisas sobre referenciação, intertextualidade e argumentação. É coordenadora do grupo de pesquisa PROTEXTO.
} 


\section{Considerações iniciais}

O emprego correto da vírgula em textos escritos em língua portuguesa é, sem dúvida, uma das maiores dificuldades que o aluno, e, muitas vezes, o próprio professor, encontra na hora de elaborar e de corrigir as redações, ou mesmo as atividades referentes ao ensino/aprendizagem das orações, quando no âmbito das aulas de sintaxe. O objetivo deste trabalho é, justamente, fornecer ao corretor de redação uma visão geral das normas que apresentam mais uniformidade entre os gramáticos e das que aparecem de maneira inconstante.

Luft (2009) diz que a dificuldade nos usos é oriunda da relação, equivocadamente ensinada, que se faz entre pausa na fala e pausa na escrita, sendo, então, a vírgula usada na escrita para marcar a pausa na fala. O autor esclarece que "a pontuação em língua portuguesa obedece a critérios sintáticos, e não prosódicos” (p.07), e que, por isso, “nem a toda pausa corresponde uma vírgula, nem a toda vírgula corresponde uma pausa” (p.07).

Luft afirma ainda que, sendo de base sintática a virgulação em língua portuguesa, não se deve separar o que é sintaticamente ligado e que, para virgular bem, é preciso que o escritor tenha um bom conhecimento das estruturas sintáticas.

O autor acusa as gramáticas normativas - doravante GN - de apresentarem regras precárias e deficientes, que não conseguem abranger todos os casos particulares. Observa ainda que, em algumas gramáticas mais atuais, de autores conceituados, persiste a ilusão da virgulação baseada em critérios prosódicos.

De fato, sobre a vírgula, Souza (2013), diz que

a gramática tradicional trata da vírgula como elemento de pontuação que marca, sobretudo, a pausa, sem dar a devida ênfase aos aspectos linguísticos e semânticos que motivam o uso da pontuação de forma enfática ou comparativa. (SOUZA, 2013, p.16).

A autora, após fazer uma leitura do que 17 GN de várias épocas dizem sobre o sinal de pontuação em foco, conclui que entre os gramáticos não há critérios uniformes para o uso da vírgula: em geral, essas obras limitam a ocorrência do sinal gráfico ao ritmo, desconsiderando, assim, os critérios sintáticos.

Compartilhando do pensamento de Luft (2009), Araújo-Chiuchi (2009) observa que as gramáticas são, com muita frequência, consultadas para análises do emprego da vírgula, mas não colaboram nesse exercício porque apresentam uma variedade de regras de usos e escolhas, gerando, desse modo, pouco consenso sobre o conjunto de normas. 
A autora acrescenta que, em consequência disso, o escrevente enfrenta uma grande variação de prescrições e orientações tanto no uso da vírgula em determinado local do parágrafo ou frase, quanto em relação ao uso de vírgula ou outro sinal de pontuação (geralmente, o ponto-e-vírgula).

Araújo-Chiuchi (2009) afirma que o problema oriundo do impasse sobre usar ou não usar uma vírgula não é, todavia, gerada apenas pelas GN, pois também se lê nos materiais didáticos que

a pontuação é predominantemente ligada à fala, mais frequentemente à pausa e a entonação (...) trata-se de uma visão da pontuação como sinais gráficos relacionados unicamente à representação de aspectos da oralidade, o que, em certa medida, revela uma visão de escrita como representação unívoca e acabada da fala. (ARAÚJO-CHIUCHI, 2009, p.02-03).

Isto é, conforme a autora, tanto nas GN quanto nos materiais didáticos persiste a ideia de que a pontuação está relacionada à pausa e à entonação da fala. Para a autora, essa concepção de pontuação é o fator que provoca muitos dos empregos da vírgula que são considerados como erros de pontuação, quando se leva em consideração as normas gramaticais sobre os itens que compõem os enunciados/frases.

Pensando em colaborar para uma correção de redação mais condizente com o maior ou o menor rigor das normas de virgulação - e mais justa, tendo em vista essa flutuação -, o PROTEXTO desenvolveu uma pesquisa em que se buscou verificar a abordagem das GN sobre o emprego da vírgula nas frases escritas em português, isto é, os casos para os quais é prescrito o uso obrigatório, o uso facultativo ou a restrição de uso do sinal, almejando que os resultados possam contribuir para o ensino de uma parte da sintaxe dessa língua, aquela que diz respeito à pontuação.

A seguir, apresentamos os procedimentos metodológicos adotados para a concretização da pesquisa.

\section{Procedimentos metodológicos}

Nesta seção, apresentamos os critérios utilizados para a seleção do material de pesquisa e como realizamos a coleta dos dados. Escolhemos as obras conforme os seguintes critérios: 
1. Referência: as gramáticas mais recorrentes em consultas de trabalhos dos estudiosos da língua em geral;

2. Ano da edição: os exemplares mais recentes, de datas que não ultrapassassem uma década em relação ao momento da pesquisa;

3. Propósitos: entre as obras escolhidas, encontram-se quatro GN usadas, hoje em dia, no ensino básico - Cegalla (2005), Cipro Neto e Infante (2006), Cunha e Cintra (2007) e Lima (2006) -, uma GN que foca concursos - Almeida (2010) e uma obra especializada no assunto do uso da vírgula, contendo, portanto, uma abordagem mais aprofundada - Luft (2009).

Uma vez realizada a escolha, efetuamos a coleta das informações em cada obra.

Para a análise dos dados, observamos detalhadamente o que cada autor apresenta, em sua respectiva obra, sobre o emprego da vírgula.

No seu livro dedicado exclusivamente à problemática do uso da vírgula, Luft (2009) afirma que, em português, o emprego deste sinal de pontuação é regido exclusivamente por critérios sintáticos, ficando de fora critérios prosódicos, como a curva melódica ou a entonação.

Aceitando esse argumento, reconhecemos como didático, e coerente, o modo como Cipro Neto e Infante (2006) abordam o assunto, pois as regras vêm distribuídas ao longo de doze páginas (349, 350, 371, 372, 391, 392, 408, 409, 426, 443, 457 e 458), que percorrem toda a seção destinada à sintaxe. Além disso, os autores dividem as regras de emprego da vírgula em subseções: primeiro, conforme cada termo da oração; depois, conforme cada tipo de oração, sejam as subordinadas ou as coordenadas, fato que evidencia a preocupação dos autores em destacar que a virgulação tem, em português, caráter essencialmente sintático.

Verificamos também que, para cada regra dada, os autores oferecem exemplos práticos e não se atêm às exceções para cada uma delas, eliminando da descrição o caráter estilístico que, algumas vezes, é atribuído à virgulação. Isso não os impede de esclarecer alguns contextos em que o uso da vírgula é facultativo.

Devido, especialmente, à opção desses dois autores de privilegiar o aspecto sintático da virgulação, elegemos essa GN como o parâmetro para a análise das demais, isto é, usamos as regras discriminadas nesse compêndio gramatical para verificar quais delas são apresentadas nas outras cinco obras e quais não são. 
Uma vez que atentamos para a nomenclatura que cada autor utiliza para nomear e descrever as regras, mesmo quando elas eram nomeadas com outros termos nas demais GN, observamos se se tratava ou não do mesmo critério e, sempre que necessário, fizemos, ao longo deste trabalho, as devidas ressalvas.

\section{Apresentação e discussão dos resultados}

Nesta seção, tecemos algumas considerações sobre os problemas encontrados no tratamento das normas de emprego e de omissão da vírgula presentes nas GN em exame. Refletimos, sobretudo, sobre as incoerências entre as regras, a ausência de regras e o excesso de casos facultativos.

\subsection{Prescrições semelhantes}

A maior parte das prescrições elencadas a seguir aparece em todas as gramáticas. Alertamos que, em Lima (2006), encontramos apenas uma regra de omissão da vírgula a que diz respeito à coordenação de termos assindéticos -, da qual falaremos mais adiante. Esclarecemos que, embora os autores divirjam na forma de apresentação de cada uma delas, de uma maneira geral, as prescrições são idênticas.

Desse modo, diz-se, consensualmente, que se a vírgula com as seguintes finalidades:

I. Para separar vocativos (ALMEIDA, 2010; CEGALLA, 2005; CIPRO NETO E INFANTE, 2006; CUNHA E CINTRA, 2007; LIMA, 2006; LUFT, 2009). Luft (2009) acrescenta que, se, no meio da frase, o termo deve ser intercalado entre duas vírgulas:

(1) “'Se eu tenho de morrer na flor dos anos, Meu Deus, não seja já!” (ALMEIDA, 2010, p. 453, grifos nossos);

(2) “'Olha, Roque, você vai me dar um remédio.” (CEGALLA, 2005, p.428, grifos nossos);

(3) "Participação crítica, cidadãos, é o caminho para um país melhor." (CIPRO NETO E INFANTE, 2006, p.392);

(4) “Que idéias tétricas, minha senhora!” (CUNHA E CINTRA, 2007, p.645, grifos nossos); 
(5) “Deixe-me, senhora.” (LIMA, 2006, p. 552, grifos nossos);

(6) “Vem muita, gente.” (LUFT, 2009, p.71, grifos nossos);

II. Para separar apostos (ALMEIDA, 2010; CEGALLA, 2005; CIPRO NETO E INFANTE, 2006; CUNHA E CINTRA, 2007; LIMA, 2006; LUFT, 2009). Almeida (2010) prescreve o uso tanto para apostos de valor explicativo, quanto para apostos oracionais. Cunha e Cintra (2007) prescrevem o uso do sinal para separar qualquer outro elemento de valor meramente explicativo. Luft (2009) faz exceção aos apostos especificativos:

(7) “E aqui, nesta serra inacessível, que deves esperar.” (ALMEIDA, 2010, p. 453, grifos nossos);

(8) “'São Marcelino Champagnat, fundador da Congregação dos Irmãos Maristas, destaca-se entre os grandes educadores da juventude. '” (CEGALLA, 2005, p.428, grifos nossos);

(9) "Caetano Veloso, compositor consagrado, não suporta quem desrespeita sinal vermelho.” (CIPRO NETO E INFANTE, 2006, p.392, grifos nossos);

(10)“Alice, a menina, estava feliz.” (CUNHA E CINTRA, 2007, p.645, grifos nossos);

(11) “'Matias, cônego honorário e pregador efetivo, estava compondo um sermão. ”” (LIMA, 2006, p. 553, grifos nossos);

(12) “O criador de Capitu, Machado de Assis, nasceu em 1839.” (LUFT, 2009, p.64, grifos nossos);

III. Para omitir verbos, ou termos, ou marcar-lhes a supressão (ALMEIDA, 2010; CEGALLA, 2005; CIPRO NETO E INFANTE, 2006; CUNHA E CINTRA, 2007; LIMA, 2006; LUFT, 2009). Todos esses autores dizem que também se deve usar vírgula para omitir uma palavra ou um grupo de palavras. Luft (2009) observa, no entanto, que essa é "uma regra artificial, apenas parcialmente confirmada na prática de bons escritores” (p.25), sendo, portanto, mais um caso de vírgula facultativa. Chamamos a atenção para o fato de que os casos de flutuação prescritiva dessa natureza levam a indecisões para o usuário comum e mais ainda para os corretores de redação. $\mathrm{O}$ autor acrescenta que, quando se marca 
a elipse de um verbo com uma vírgula, a pontuação anterior - aquela que separa as orações - deve ser maior: ponto-e-vírgula ou ponto:

(13) ““Na sala, apenas quatro ou cinco convidados.’ A vírgula indica a supressão da forma verbal havia ou estavam.” (ALMEIDA, 2010, p. 453);

(14) "Uns dizem que se matou, outros, que fora para o Acre. [=outros diziam que fora para o Acre.]” (CEGALLA, 2005, p.429, , grifos no original);

(15) “Eu trabalho com fatos; você, com boatos.” (CIPRO NETO E INFANTE, 2006, p.350);

(16) “No céu azul, dois fiapos de nuvem.” (CUNHA E CINTRA, 2007, p.646);

(17) ““Uma flor, o Quincas Borba.’” (LIMA, 2006, p.553);

(18) “Sou gremista; eles, colorados.” (LUFT, 2009, p.26);

IV. Para separar o adjunto adverbial anteposto ou intercalado (ALMEIDA, 2010; CEGALLA, 2005; CIPRO NETO E INFANTE, 2006; CUNHA E CINTRA, 2007; LIMA, 2006; LUFT, 2009). Esta norma é uma das que mais apresentam imprecisões. Almeida (2010) afirma que a regra vale tanto para o termo deslocado quanto para o termo intercalado (ex. 19a); mas, sendo curto o adjunto adverbial, dispensa-se a vírgula (ex. 19b). As dificuldades começam na determinação daquilo que é considerado "adjunto adverbial curto”: como os usuários da língua e corretores de redação decidirão sobre o limite de extensão de adjunto adverbial que deve ser marcado por vírgula por estar deslocado de sua posição canônica na sentença? Cunha e Cintra (2007) e Lima (2006) falam apenas do adjunto adverbial antecipado e afirmam que, se o termo for curto, mesmo que venha deslocado, dispensa-se a vírgula (ex. 22a e 22b e 23, respectivamente). Cegalla (2005) não indica em qual posição - se antecipado ou intercalado - deve estar o termo para que este seja separado. Seus exemplos, contudo, exibem apenas o termo antecipado. Luft (2009), por sua vez, diz que, quando o adjunto adverbial vem intercalado, usam-se “ou duas vírgulas (...), ou nenhuma.” (p.31), obviamente referindo-se às situações de intercalação e anteposição, respectivamente. Cipro Neto e Infante (2006) chegam a afirmar que é facultativo se separar, por vírgula, 
o adjunto adverbial quando este vem após o verbo e seu(s) complemento(s) (ex. 21a), porém explicam, logo em seguida, que a separação é obrigatória quando o termo está anteposto ou intercalado, mas dispensável quando o adjunto é de pequena extensão (ex. 21b). A indefinição paira, portanto, sobre marcar ou não com vírgulas o deslocamento de adjuntos adverbiais considerados “curtos” e sobre quão curtos devem ser os casos que dispensariam as vírgulas:

(19a) "Uma noite, no seio da cabana, a virgem de Tupã tornou-se esposa de Martim.” (ALMEIDA, 2010, p. 453, grifos nossos);

(19b) “O estudo sempre se torna um sacrifício.” (ALMEIDA, 2010, p. 453, grifos nossos);

(20a) “"Eis que, aos poucos, lá para as bandas do oriente, clareia um cantinho do céu."” (CEGALLA, 2005, p.429, grifos nossos);

(20b) "'Dentro do navio homens e mulheres conversavam." (CEGALLA, 2005, p.429, grifos nossos);

(21a) “'Encontrei alguns amigos, ontem à noite, na praça' ou 'encontrei alguns amigos ontem à noite na praça’”. (CIPRO NETO E INFANTE, 2006, p.391, grifos nossos);

(21b) " Ontem à noite, encontrei alguns amigos na praça. (...) Ali se vendem esses produtos.’” (CIPRO NETO E INFANTE, 2006, p.391, grifos nossos);

(22a) "Lá fora, a chuvada despenhou-se por fim." (CUNHA E CINTRA, 2007, p.645, grifos nossos);

(22b) "Depois levaram o Ricardo para a casa da mãe Avelina.” (CUNHA E CINTRA, 2007, p.646, grifos nossos);

(23) “'Por impulso instantâneo, todo o ajuntamento se pôs de pé’” (LIMA, 2006, p.553, grifos nossos);

(24) “Ou, se houver necessidade, serão feitas algumas alterações.” (LUFT, 2009, p.32, grifos nossos);

V. Para separar/isolar a oração subordinada adjetiva explicativa da sua principal (ALMEIDA, 2010; CEGALLA, 2005; CIPRO NETO E INFANTE, 2006; CUNHA E CINTRA, 2007; LIMA, 2006; LUFT, 2009). Todos os autores explicam, à exceção de Cegalla (2005), com critérios semânticos, os porquês dessas normas. Não nos ocuparemos aqui de tais justificativas, todas relacionadas à distinção sintática entre orações subordinadas adjetivas restritivas e explicativas. Esta prescrição se mostra, assim, consensual: 
(25) “E essa força, que é tudo, vem de um nada.” (ALMEIDA, 2010, p. 455, , grifos no original);

(26) “'O coronel ia enchendo o tambor do revólver, do qual nunca se separava.”” (CEGALLA, 2005, p.429, grifos nossos);

(27) "O país, cuja distribuição de renda é indecente, não tem perspectiva de civilizar-se.” (CIPRO NETO E INFANTE, 2006, p.426, grifos nossos);

(28) "O Loas, que tinha relações sobrenaturais, diagnosticara um espírito.” (CUNHA E CINTRA, 2007, p.649, grifos nossos);

(29) “'A ele, que é o descanso da corporação, nenhum preito lhe renderam.”” (LIMA, 2006, p.557, grifos nossos);

(30) "Em cima havia uma salinha, [que era] mal iluminada por uma janela que [a janela] dava para o telhado dos fundos.” (LUFT, 2009, p.56, grifos nossos

VI. Para separar orações coordenadas assindéticas (ALMEIDA, 2010; CEGALLA, 2005; CIPRO NETO E INFANTE, 2006; CUNHA E CINTRA, 2007; LIMA, 2006; LUFT, 2009). Os autores analisados são também unânimes no estabelecimento desta norma. Luft (2009), todavia, não apresenta exemplos para essa norma:

(31) "No alto da figueira estava, no alto da figueira fiquei." (ALMEIDA, 2010, p. 454);

(32) “'Os passantes chegam, olham, perguntam e prosseguem.” (CEGALLA, 2005, p.428);

(33) “Alguns reclama, um ou outro protesta, ninguém reivindica."” (CIPRO NETO E INFANTE, 2006, p.457);

(34) “Pois eu caçaca, visgava, alçapava.” (CUNHA E CINTRA, 2007, p.647);

(35) “‘Há sol, há muito sol, há um dilúvio de sol.’” (LIMA, 2006, p.555);

Vale ressaltar, neste ponto, o que as gramáticas costumam prescrever sobre a vírgula antes do ' $e$ ' que inicia oração coordenada sindética aditiva. (ALMEIDA, 2010; CIPRO NETO E INFANTE, 2006; CUNHA E CINTRA, 2007; LIMA, 2006), advertem que se deve usar a vírgula antes do $e$ quando os sujeitos das duas orações forem diferentes.

(36) “Um deitou-se na rede, e outro telefonava.” (ALMEIDA, 2010, p. 455, 
grifos nossos);

(37) "O presidente convocou os ministros, e o Congresso começou a trabalhar.” (CIPRO NETO E INFANTE, 2006, p.458, grifos nossos);

(38) “O sol já ia fraco, e a tarde era amena.” (CUNHA E CINTRA, 2007, p.647, grifos nossos);

(39) “"Veio a noite do baile, e a baronesa vestiu-se.”” (LIMA, 2006, p.555, grifos nossos);

Assim, recomenda-se que não se use a vírgula antes do ' $e$ ' que inicia oração coordenada quando os sujeitos das duas orações são os mesmos (CIPRO NETO E INFANTE, 2006; CUNHA E CINTRA, 2007; LUFT, 2009). Luft (2009), no entanto, alega que a vírgula é facultativa antes da conjunção $e$ quando a parte esquerda da coordenação for muito longa. Mais uma vez, deparamo-nos com a imprecisão do que pode ser considerado "muito extenso", o que contribui para interpretações diferentes quanto à norma. Almeida (2010), Cegalla (2005) e Lima (2006) nada falam sobre o assunto;

Esclarecemos que não se deve confundir este uso da vírgula com aquele em que apenas se separam termos. Almeida (2010), Cipro Neto e Infante (2006) e Cunha e Cintra (2007) prescrevem o uso do sinal para os casos de polissíndetos e para os casos em que a conjunção não tem valor aditivo. Em Cegalla (2005), não encontramos nada sobre essa regra. Lima (2006) também cita o emprego do sinal "para acentuar, numa estrutura, o vulto das coisas enumeradas” (p. 555), isto é, os casos de polissíndetos;

(40a) "Ele fez o céu, $e$ a terra, $e$ o mar, $e$ tudo quanto há neles." (ALMEIDA, 2010, p. 455, grifos nossos);

(40b) “'Estudou o ano inteiro, e não conseguiu aprovação no concurso.' (valor adversativo)”. (ALMEIDA, 2010, p. 455);

(41) "O menino girava em volta da mãe, e vinha, e tornava a ir, e ainda uma vez voltava, e se afastava, e ameaçava falar o que queria, e fazia meia-volta..." (CIPRO NETO E INFANTE, 2006, p.458);

(42) “E eles riem, e eles cantam, e eles dançam.” (CUNHA E CINTRA, 2007, p.647);

(43) “'Seca a terra aparece, e nela é tudo informe, e rude, e solitário, e mudo.”” (LIMA, 2006, p.555); 
VII. Vírgula antes das orações coordenadas iniciadas por conjunções adversativas, alternativas, conclusivas ou explicativas (ALMEIDA, 2010; CIPRO NETO E INFANTE, 2006; LIMA, 2006). Cunha e Cintra (2007) prescrevem o uso da vírgula apenas para as orações coordenadas iniciadas por conjunções adversativas ou conclusivas.

(44) "O senhor (...) estava avisado do que ia acontecer, portanto não chore mais.” (ALMEIDA, 2010, p. 454, grifos nossos);

(45) "A queimada das florestas nativas representa grande desperdício, mas continua a ser praticada neste país.” CIPRO NETO E INFANTE, 2006, p.457, grifos nossos);

(46) "Vá aonde quiser, porém fique morando conosco." (CUNHA E CINTRA, 2007, p.648, grifos nossos);

(47) “'Não se deve julgar o homem por uma só ação, senão por muitas.” (LIMA, 2006, p.556, grifos nossos);

Até este momento, discutimos as normas mais ou menos consensuais de emprego da vírgula. Agora, trataremos das situações em que os autores proíbem a virgulação. Assim, não se usa vírgula:

I. Entre o sujeito e o predicado/verbo (ALMEIDA, 2010; CEGALLA, 2005; CIPRO NETO E INFANTE, 2006; LUFT, 2009). Nesta norma, as recomendações se distanciam um pouco do que se costuma encontrar em alguns textos literários clássicos e em uma outra opinião, de Evanildo Bechara (2009), não utilizada na análise deste trabalho. Isso pode colaborar para correções diferenciadas e, consequentemente, para uma atribuição diferenciada de pontos às redações. De um modo geral, sustenta-se que não se separa sujeito de predicado. Para Almeida (2010) e Luft (2009), por exemplo, não se usa vírgula nem mesmo quando o sujeito é extenso. Luft (2009) acrescenta que a vírgula pode ser usada aos pares, para marcar encaixe(s). Cegalla (2005) afirma que "não se emprega vírgula entre o sujeito e o verbo da oração, quando juntos” (p.429), o que nos permite a interpretação de que, quando separados, deve-se usá-la. Esse modo de enunciar a norma abre espaço para a indefinição: sempre que sujeito e verbo estiverem "separados”, deve-se empregar a vírgula? Se pensarmos, no entanto, na intercalação de adjuntos adverbiais entre o sujeito e o verbo, caímos na mesma 
dúvida sobre a virgulação nos adjuntos adverbiais deslocados. Cipro Neto e Infante (2006) repetem a recomendação de Almeida (2010) e de Luft (2009): não se usa vírgula nem mesmo quando o sujeito é muito longo ou vem depois do predicado. Todavia, lemos em Bechara (2009) que há um caso em que é possível (mas não obrigatório) pôr vírgula entre sujeito e predicado. Isso aconteceria depois de um sujeito expandido pela oração adjetiva: “Os que falam em matérias que não entendem, parecem fazer gala da sua própria ignorância [M.M]” (BECHARA, 2009, p. 610). Cunha e Cintra (2007) não fazem menção a esta regra diretamente, porém alegam que "os termos essenciais e integrantes da oração se ligam uns com os outros sem pausa; não podem, assim, ser separados com vírgula” (p.650). A tendência, mas não o consenso, é que não se deve empregar a vírgula entre o sujeito e o predicado;

(48) "A sua compleição robusta / ostenta-se nesta ocasião em toda a plenitude.” (ALMEIDA, 2010, p. 456);

(49) "Atletas de várias nacionalidades participarão da grande maratona." (CEGALLA, 2005, p.429);

(50) "Todas as tentativas de mudar a relação entre trabalho capital e trabalho resultaram em fracassos.” (CIPRO NETO E INFANTE, 2006, p.349)

(51) “O Jardim de Infância Vovô Ruy tratará o seu filho como...” (LUFT, 2009, p.23);

II. Entre o verbo e seus complementos (ALMEIDA, 2010); CEGALLA, 2005; CIPRO NETO E INFANTE, 2006; LUFT, 2009). Almeida (2010) alerta que não se deve separar, com vírgula, o verbo do seu complemento nem mesmo se o objeto indireto antepuser o objeto direto. Cegalla (2005) afirma que "não se emprega vírgula entre o verbo e seus complementos, quando juntos” (p.430), o que permite a interpretação de que, quando separados, deve-se usá-la. Cipro Neto e Infante (2006) dizem que não se deve pôr vírgula nem mesmo nos casos em que o complemento estiver anteposto ao termo que completa.

(52) “Pagarei ao farmacêutico a conta.” (ALMEIDA, 2010, p. 456);

(53) “'Dona Elza pediu ao diretor que colocasse o filho em outra turma.,” (CEGALLA, 2005, p.430); 
(54) "É preciso saber reagir às palavras dos provocadores com lucidez." (CIPRO NETO E INFANTE, 2006, p.371);

(55) “O estudante comprou livros.” (LUFT, 2009, p.12);

\subsection{Os casos (mais) divergentes}

De início, destacamos alguns problemas que encontramos na obra de Lima (2006) quanto ao tratamento do emprego da vírgula. Dentre eles, apontamos a divisão de uso e não uso do sinal. Como mencionamos anteriormente, o autor apresenta apenas as regras de uso e apenas uma regra de omissão da vírgula, não esclarecendo em quais outros contextos sintáticos da oração não se deve usá-la. Além disso, salvo o caso dos adjuntos adverbiais, do qual falaremos mais adiante, o autor não expõe outros casos de uso facultativo. A omissão nos leva a entender, talvez precipitadamente, que, em todos os outros ambientes sintáticos que não aqueles contemplados pelas regras de uso, não se deverá usar a vírgula.

Fator agravante da situação é a quantidade imensa de exemplos retirados de obras de grandes nomes das literaturas de língua portuguesa, o que lhes atribui caráter estilístico, visto que o texto literário, não é novidade, tem um estilo bem diferenciado do texto jornalístico, do texto publicitário e dos textos das redações oficiais.

Apontamos o problema referente à presença de regras em algumas obras e ausência delas em outras, como, por exemplo, a regra que prescreve o emprego da vírgula para isolar o objeto direto ou indireto pleonástico, que é citada apenas por Almeida (2010) e Cipro Neto e Infante (2006), como no exemplo:

(56) ““Ao ingrato, eu não o sirvo porque me não magoe.’” (ALMEIDA, 2010, p. 454, grifos no original);

(57) “Aquelas frutas, plantara-as na primavera." (CIPRO NETO E INFANTE, 2006, p.371);

Assim também acontece com a norma que prescreve uso facultativo de vírgula entre o verbo passivo, o agente da passiva e o sujeito passivo, citada apenas por Luft (2009). A norma é descrita de modo confuso, pois o autor se contradiz, visto que, em outras páginas, ele diz que não se deve usar vírgula nem entre o sujeito e o predicado, nem entre o verbo e os seus complementos. Além disso, chamamos a atenção para a maneira como uma mesma regra vem apresentada nas diferentes obras. Cegalla (2005), 
por exemplo, fala que a vírgula pode ser empregada para separar "termos que desejamos realçar” (p.430) e dá um exemplo de uma frase com um objeto direto pleonástico antecipado:

(58) "o dinheiro, Jaime o trazia escondido nas mangas do paletó" (CEGALLA, 2005, p. 430, grifos nossos);

Sabemos que tanto o objeto direto como o objeto indireto pleonástico são termos realçados, entretanto, não apenas eles, mas muitos outros termos podem ser realçados.

O problema é criado quando o autor usa a palavra realçar, que faz parte do mesmo campo semântico de enfatizar. Um advérbio de intensidade, por exemplo, pode receber uma ênfase maior na fala, sendo, pelo aluno/escritor, conforme a regra do autor citado, isolado do restante da frase, gerando uma frase como a do exemplo seguinte:

(59) Naquele dia nós andamos, tanto!

Parece-nos confusa e vaga a explicação sobre o uso da vírgula para separar esses termos que desejamos realçar, principalmente se levarmos em consideração que os alunos, por teimosia ou não conhecimento/compreensão da composição das frases, costumam levar para a escrita as pausas da fala.

Apontamos ainda um problema referente aos casos facultativos de emprego da vírgula. Sobre a vírgula nas subordinadas adverbiais, Cipro Neto e Infante (2006) dizem que "a separação é optativa quando a oração subordinada está posposta à principal e é obrigatória quando a oração está intercalada ou anteposta” (p.443); Lima (2006), por outro lado, diz que se deve usar vírgula para separar a oração subordinada adverbial, reduzida ou desenvolvida, da principal, quer aquela venha anteposta ou quer venha posposta a esta. Desse modo, para uma mesma situação - a posposição da subordinada adverbial - Cipro Neto e Infante (2006) apontam uso facultativo, ao passo que Lima (2006) aponta uso obrigatório.

(60) “'Tudo continuará como está se você não intervier' ou 'Tudo continuará como está, se você não intervier.” (CIPRO NETO E INFANTE, 2006, p.443, grifos nossos);

(61a) “Juro que ela sentiu certo alívio, quando os nossos olhos se encontraram...” (LIMA, 2006, p.557, grifos nossos);

(61b) “"Enquanto o senhor escarneceu o feitio das minhas botas, estava no 
seu ofício e no seu direito.’” (LIMA, 2006, p.557, grifos nossos);

Ainda sobre as orações subordinadas adverbiais, apontaremos a seguir uma divergência sobre o uso, ou não, da vírgula antes da adverbial consecutiva.

\subsubsection{A vírgula e a oração subordinada adverbial consecutiva}

A prescrição do emprego ou da omissão da vírgula antes da oração subordinada adverbial consecutiva vem apresentada em apenas duas obras: a de Cegalla (2005) e a de Lima (2006).

Lima (2006) adverte que se deve usar vírgula para separar a oração subordinada adverbial consecutiva da sua principal, assim:

(62) "(...) e o fulgor das pupilas negras fuzilava tão vivo e por vezes tão recobrado, que se tornava irresistível.” (LIMA, 2006, p. 556, grifos no original).

Isso está em conformidade com a regra apresentada pelo autor para as orações subordinadas adverbiais: usa-se a vírgula "para separar as orações subordinadas adverbiais (iniciadas pelas conjunções subordinativas não integrantes), quer antepostas, quer pospostas à principal.” (LIMA, 2006, p.556).

Seguindo o argumento de Luft (2009), que afirma ser a vírgula um sinal de pontuação que indica falta ou quebra de ligação sintática no interior das frases, verificamos um equívoco na regra imposta pelo gramático Rocha Lima, pois, na estrutura da oração subordinada adverbial consecutiva, encontramos um elemento que depende sintaticamente de outro que está na oração principal, como os vocábulos tão, tão e que, que o autor utiliza no seu exemplo, transcrito em (3). Vejamos outro exemplo:

(63) Ontem choveu tanto / que inundou tudo.

Como podemos observar, a conjunção integrante que inicia a oração subordinada consecutiva depende - sintática e semanticamente - do advérbio de intensidade que pertence à principal. Este pode, às vezes, vir elíptico. Colocar vírgula entre esses dois itens significa 'quebrar' o conjunto da frase e criar uma separação que não deveria existir, alegando que entre os dois itens não há nenhuma ligação sintática. 
Cegalla (2005), por sua vez, diz que não se deve usar vírgula para separar a subordinada adverbial consecutiva da sua principal. Embora essa regra seja bem coerente com o critério sintático da sentença é, todavia, destoante de outra regra do mesmo autor que diz: não se deve usar vírgula para separar a oração subordinada adverbial - tanto a reduzida como a desenvolvida - da principal.

Percebemos, então, dois problemas: o primeiro diz respeito ao fato de se poder ou não usar a vírgula para separar a oração subordinada adverbial consecutiva da sua principal, uma vez que dois conceituados autores ditam regras diferentes; o segundo diz respeito à falha de Cegalla quanto à definição das regras para as orações subordinadas adverbiais em geral, desenvolvidas ou reduzidas. Em um primeiro momento, este autor afirma que se deve usar vírgula para separá-las das suas respectivas principais; em outro, ele coloca uma restrição à regra e afirma que não se usa vírgula entre a consecutiva e a sua principal.

Por fim, acrescentamos que não encontramos em nenhuma das obras uma regra específica que esclareça se se deve, ou não, usar vírgula para separar as orações subordinadas adverbiais finais das suas principais. Também não encontramos nada que prescreva o emprego ou a omissão de vírgulas entre as orações subordinadas adverbiais concessivas e suas respectivas regentes, nem entre as condicionais e suas regentes. Encontramos apenas as informações sobre as adverbiais em geral, com todas as problemáticas apontadas.

\subsubsection{O tamanho do adjunto adverbial}

Por ser a norma que mais flutuação admite nas correções de redação, retornamos, agora, ao uso de vírgulas para separar ou intercalar o adjunto adverbial.

Esta norma, mesmo estando presente em todas as obras, sendo, à primeira vista, igual em todas, vem apresentada de maneiras diversas: Cunha e Cintra (2007), por exemplo, falam apenas do adjunto adverbial antecipado, sem dizer se se deve ou não usar a vírgula para separar o adjunto adverbial que vem intercalado no meio da frase.

Cegalla (2005) adverte que o adjunto adverbial deve ser separado por vírgula, mas não informa em qual posição o termo em questão deve estar para que se aplique o sinal de pontuação, se antecipado ou intercalado. O autor apresenta três exemplos, um com dois adjuntos intercalados entre vírgulas: 
(64) “'eis que, aos poucos, lá para as bandas do oriente, clareia um cantinho do céu.” (CEGALLA, 2005, p.329, grifos no original)

e o outro com o termo antecipado:

(65) “com mais de setenta anos, andava a pé.” (CEGALLA, 2005, p.329, grifos no original);

do terceiro exemplo falaremos mais à frente.

Lima (2006) menciona apenas o caso do adjunto adverbial invertido e apresenta o seguinte exemplo:

(66) "por impulso instantâneo, todo o ajuntamento se pôs de pé.” (LIMA, 2006, p.553, grifos nossos);

Luft (2009), sobre essa questão, diz que, quando o termo está intercalado, usamse duas vírgulas para separá-lo ou nenhuma, mas nunca só uma. Por outro lado, o autor termina por se contradizer ao afirmar que não se usa vírgula para separar o advérbio quando este está entre o verbo e o seu complemento. Como o adjunto adverbial pode também ser expresso por apenas um advérbio, o autor nos põe a dúvida: afinal, deve-se ou não separar dos outros termos o adjunto adverbial que está intercalado?

Outro problema surge com as prescrições de Almeida (2010), Cipro Neto e Infante (2006), Cunha e Cintra (2007) e Lima (2006) que dizem que, se o termo for curto, como, por exemplo, apenas um advérbio ou uma locução adverbial, não deve ser separado do restante da oração.

Como dissemos no início deste trabalho, para nós, essa explicação é vaga, pois ficamos sem saber o que é um adjunto adverbial curto. Se um adjunto adverbial for considerado curto quando apresentar apenas um vocábulo - um advérbio, no caso quantos vocábulos serão necessários para que se considere um adjunto adverbial longo?

Acrescentamos que Souza (2013), consultando outras GN, além destas que usamos neste trabalho, deparou-se com o mesmo problema: "outra regra que não apresenta critérios claros é a de que 'adjuntos de pequeno corpo'(...) podem dispensar a vírgula. O que podemos entender por pequeno corpo?” (p.32). Para ela, esse critério, além de não ser coerente, não é facilmente compreendido e aplicado pelos estudantes. A autora acusa as GN analisadas de não usarem precisão vocabular para formular essa norma. Reflitamos sobre as três frases seguintes: 
(67) Ontem choveu muito.

(68) Ontem à tarde choveu muito.

(69) Na tarde de primeiro de janeiro de mil novecentos e noventa e nove choveu muito.

Em todos os três exemplos, temos, antes do verbo, um adjunto adverbial de tempo. O segundo deles é maior que o primeiro e menor que o terceiro. Deve-se ou não separálo do restante da frase? Qual seria, afinal, o critério a ser adotado para que se possa considerar um adjunto adverbial curto ou longo?

Os autores dizem que um adjunto adverbial é curto quando o termo apresenta apenas um advérbio ou uma locução adverbial. Para o primeiro caso - só um advérbio -, a explicação é satisfatória. Para o segundo - uma locução adverbial -, todavia, a explicação, e muito menos os exemplos apresentados, não elucidam a questão, pois as locuções variam em dimensão e quantidade de itens vocabulares.

Observemos o segundo - que repetimos logo abaixo - e o terceiro exemplos que Cegalla (2005) apresenta sobre os adjuntos adverbiais:

(65) “com mais de setenta anos, andava a pé.” (CEGALLA, 2005, p.329, grifos no original);

(70) “dentro do navio homens e mulheres conversavam.” (CEGALLA, 2005, p.329, grifos no original);

Nos dois exemplos, temos adjuntos adverbiais antecipados, oportunamente não constituídos por apenas um advérbio, uma locução adverbial, portanto. No primeiro deles, o termo vem separado com vírgula; no segundo, não há vírgula.

Os exemplos de Cunha e Cintra (2007) são menos esclarecedores ainda, pois trazem um mesmo adjunto adverbial antecipado, que ora é separado por vírgula, ora não o é:

(71) “Depois levaram Ricardo para a casa da mãe Avelina.” (CUNHA E CINTRA, 2007, p.646, grifo nossos);

(72) “Depois, tudo caiu em silêncio.” (CUNHA E CINTRA, 2007, p.646, grifo nossos); 
Cipro Neto e Infante (2006), por fim, dizem que é facultativo usar a vírgula para separar o adjunto adverbial que está depois do verbo e seus complementos. O emprego do sinal é, todavia, obrigatório quando o termo estiver intercalado ou anteposto. Os autores, assim como todos os outros, caem no dilema da extensão (sempre imprecisa) do adjunto adverbial.

\subsubsection{Vírgula entre a oração principal e a subordinada adjetiva restritiva}

Apenas Cipro Neto e Infante (2006) e Luft (2009) fazem referência às adjetivas restritivas e à possibilidade, ou não, de se usar vírgula antes delas, separando-as das suas respectivas principais.

Os primeiros dizem que não se usa vírgula nem mesmo nos casos em que a oração subordinada adjetiva for muito longa. Luft (2009), por sua vez, alega que, nesses casos, a vírgula pode ser usada e que isso configura, portanto, um caso de facultatividade.

Temos, mais uma vez, duas prescrições diferentes para o mesmo ambiente sintático.

\subsubsection{Outros casos}

Nesta seção, discutimos algumas das normas que constam em apenas uma obra, sem problematização. Mencionamos, oportunamente, o autor que as apresenta, a fim de que possamos observar algumas divergências a mais no confronto das obras analisadas:

Almeida (2010) diz que se usa vírgula para isolar topônimos seguidos de data:

(73) “São Paulo, 21 de setembro de 2002.” (ALMEIDA, 2010, p.454);

Cegalla (2005) diz que se usa a vírgula para separar os elementos paralelos de um provérbio:

(74) “Mocidade ociosa, velhice vergonhosa.” (CEGALLA, 2005, p.429);

Cunha e Cintra (2007) dizem que se usa vírgula para isolar os elementos repetidos:

(75) “Só minha, minha, minha, eu quero!...” (CUNHA E CINTRA, 2007, p.645);

Lima (2006) afirma que se usa vírgula nas datas: 
(76) “31, janeiro, 1902.” (LIMA, 2006, p.553);

Luft (2009) acrescenta que se usa vírgula para evitar ambiguidades:

(77a) "O aluno trabalha, segundo o professor / o aluno trabalha segundo o professor” (LUFT, 2009, p.10);

(77b) “Não fala, de medo / não fala de medo” (LUFT, 2009, p.10).

Este trabalho constata, assim, que, dada a imprecisão e a divergência entre gramáticos e entre autores de compêndios gramaticais, é necessário ponderar sobre a punição aplicada às redações nos casos em que não as normas não são consensuais.

A exposição das divergências e da oscilação entre as prescrições para o uso da vírgula presentes nos seis compêndios analisados neste trabalho nos levam ao seguinte questionamento: qual deve ser a GN mais adequada para a consulta em sala de aula/concursos? Qual obra deve ser tomada como norte para a correção de redações e/ou outros textos escritos?

Diante das conclusões a que chegamos nesta pesquisa, não há como responder satisfatoriamente a essas indagações. Longe de querer resolver o impasse das prescrições entre os autores das obras em foco ou de indicar uma GN como a mais correta, este trabalho propõe apenas uma breve reflexão sobre como essa oscilação prescritiva se reflete no ensino e que problemas ela pode ocasionar.

\section{Considerações finais}

Neste trabalho, mostramos os resultados de uma pesquisa que procurou trazer a nu as divergências e as oscilações nas prescrições sobre o emprego correto da vírgula existentes entre algumas GN.

Os resultados da nossa pesquisa apontam algumas divergências nas abordagens sobre o emprego da vírgula por parte dos renomados autores, como, por exemplo, as contradições, na obra de Cegalla (2005), entre as normas que, para o mesmo contexto sintático - no caso, as orações subordinadas adverbiais - ora afirmam a necessidade de emprego do sinal, ora a negam.

Apontam também a ausência de regras, na obra de Lima (2006), que prescrevam os casos em que o sinal não deve ser utilizado. Além disso, há regras apresentadas em 
uma obra e ausentes em outras; também há vagueza na exposição das regras, não recompensada pelos exemplos dados, entre outros problemas.

Esses resultados colaboram para afirmar que as regras explícitas das nossas gramáticas e manuais de português ainda permitem interpretações divergentes, o que pode repercutir negativamente na correção de redações. As regras são, por vezes, "não suficientemente gerais e precisas para abranger casos particulares” (LUFT, 2009, p.08).

Vimos, desse modo, que nem mesmo alguns dos manuais que deveriam apresentar, com absoluto rigor, o emprego correto da vírgula escapam de derrapar em imprecisões e omissões.

Verificamos também que, embora amparadas pela Norma Gramatical Brasileira, NGB, as obras aqui investigadas apresentam algumas diferenças no tratamento de um mesmo objeto, isto é, divergem em alguns critérios para a correta virgulação em língua portuguesa. Os resultados nos fazem vislumbrar quanto ainda poderíamos encontrar divergências entre as prescrições se fosse feito um levantamento dos dados de todas as GN de língua portuguesa. A considerar o expressivo número de gramáticas normativas à venda no mercado, muitas delas, obviamente, não puderam ser contempladas na nossa pesquisa.

Não pretendemos que os resultados da nossa pesquisa resolvam o impasse entre as prescrições dos gramáticos. Esperamos tão-somente que este trabalho possa contribuir para gerar reflexões e para ampliar os horizontes do ensino das regras de utilização da vírgula. É necessário que o professor considere a divergência que existe entre os argumentos dos autores desses compêndios prescritivos e pondere sobre o que, efetivamente, deve ser considerado certo ou errado nas avaliações de seus alunos.

A divergência de critérios na correção das redações poderia ser, senão sanada, ao menos reduzida, se as prescrições fossem unânimes nas GN produzidas em língua portuguesa. Esta discussão se configura como uma tentativa de trazer ao professor novas perspectivas para o ensino de redação, pois, se é realmente o ponto-de-vista que faz o objeto, e o conhecimento deve ser dado a todos que o buscam, acreditamos que aos alunos, assim como aos professores, não pode ser negada a perspectiva de diversos olhares sobre o mesmo objeto. 


\section{Referências bibliográficas}

ALMEIDA, N. T. de. Gramática da língua portuguesa para concursos. $9^{\mathrm{a}}$ ed. revista e atualizada. 4a tiragem. São Paulo: Saraiva, 2010.

ARAÚJO-CHIUCHI, A. C. O uso de vírgulas: evidências da heterogeneidade da escrita. Estudos Linguísticos, São Paulo, n. 40 (2), p. 488-497, mai./ago. 2011.

BECHARA, E. Moderna gramática portuguesa, $37^{a}$ ed. Rio de Janeiro: Nova Fronteira, Lucerna, 2009.

CEGALLA, D. P.. Novíssima gramática da língua portuguesa. $46^{a}$ ed. são Paulo: Companhia Editora Nacional, 2005.

CIPRO NETO, P.; INFANTE, U. Gramática da língua portuguesa. $2^{\mathrm{a}}$ ed. São Paulo: Scipione, 2006.

CUNHA, C. F. da; CINTRA, L. F. L. Nova gramática do português contemporâneo. $3^{\mathrm{a}}$ ed. Rio de Janeiro: Lexicon Informatica, 2007.

LIMA, C. H. da R.. Gramática normativa da língua portuguesa. $48^{\mathrm{a}}$ ed. Rio de Janeiro: José Olympio, 2006.

LUFT, C. P.. A vírgula: considerações sobre o seu ensino e o seu emprego. $2^{\text {a }}$ ed. São Paulo: Ática, 2009.

SOUZA, I. G. de. Sobre o uso da vírgula: em redações, em gramáticas e para a linguística. 2013. 77 f. Dissertação de mestrado (Mestrado em Linguística). Departamento de Linguística, Português e Línguas Clássicas, Universidade Federal de Brasília, Brasília, 2013.

Artigo recebido em: 28.02.2015

Artigo aprovado em: 09.06.2015 